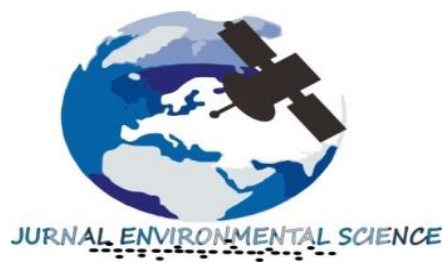

Jurnal EnvironmentaI Science

Volume 1 Nomor 1 Oktober 2018.

p-ISSN : 2654-4490 dan e-ISSN : 0000-0000

Homepage at : ojs.unm.ac.id/JES

E-mail:jes@unm.ac.id

\title{
Pemetaan Objek Wisata Bahari Kabupaten Kepulauan Selayar Berbasis Sistem Informasi Geografi
}

\author{
Ali Rahmat Muhammadiyah Nur \\ Jurusan Geografi, Fakultas Matematika dan Ilmu Pengetahuan Alam,
}

Universitas Negeri Makassar, 2018, Indonesia

\begin{abstract}
The purpose of this study was to determine (1) how the management of marine tourism objects carried out by the Selayar Islands Regency government; (2) How to map the Selayar Islands Regency marine tourism object based on geographic information systems. This type of research is qualitative with descriptive method. Data collection techniques used in this study are observation techniques, field measurement techniques, interview techniques and documentation techniques in collecting data. The results of this study are (1) Management of the Selayar Islands Regency marine tourism object is a management that in addition to paying attention to the preservation aspect also provides participation to the community as planners, implementers and managers of marine tourism objects. Not yet formed a tourism conscious society as a whole causes planning, implementation up to the management of marine tourism objects is not optimal; (2) There are 38 marine tourism objects in Selayar Islands Regency, 22 of them have been studied and 16 others have not been studied.
\end{abstract}

Keywords: Marine Tourism Object, GIS

\section{ABSTRAK}

Tujuan penelitian ini adalah untuk mengetahui (1) Bagaimana pengelolaan objek wisata bahari yang dilakukan oleh pemerintah Kabupaten Kepulauan Selayar; (2) Bagaimana pemetaan objek wisata bahari Kabupaten Kepulauan Selayar berbasis sistem informasi geografi. Jenis penelitian ini adalah kualitatif dengan metode deskriptif.). Hasil penelitian ini adalah (1) Pengelolaan objek wisata bahari Kabupaten Kepulauan Selayar merupakan pengelolaan yang selain memperhatikan aspek pelestarian juga memberikan peran serta kepada masyarakat sebagai perencana, pelaksana dan pengelola objek wisata bahari. Belum terbentuknya masyarakat sadar wisata secara utuh menyebabkan perencanaan, pelaksanaan hingga pada pengelolaan objek wisata bahari belum maksimal; (2) Terdapat 38 objek wisata bahari Kabupaten Kepulauan Selayar, 22 diantaranya telah terkelolah dan 16 lainnya belum terkelola.

Kata Kunci : Objek Wisata Bahari, SIG 


\section{PENDAhULUAN}

Sektor pariwisata adalah sektor ekonomi yang dapat memanfaatkan lingkungan alami dan buatan manusia sebagai tempat untuk menghasilkan pendapatan (Van der Merwe dan Van Niekerk, 2013). Dilihat dari jumlah orang yang terlibat maupun uang yang beredar di dalamnya, pariwisata adalah industri yang paling besar di dunia (Cahyadi dan Gunawijaya, 2009). Keberhasilan Industri pariwisata dalam suatu negara ditentukan oleh sejauh mana negara tersebut dapat mengembangkan, mengelola dan mempromosikan sumberdaya wisata yang dimilikinya (Cvetković dan Jovanović, 2016).

Dalam mengembangkan sektor pariwisata, pemasaran produk wisata menjadi faktor penting untuk meningkatkan jumlah kunjungan wisata. Salah satu teknologi yang dapat digunakan untuk menciptakan sistem informasi pariwisata ini adalah SIG (Sistem Informasi Geografi). Aplikasi SIG dalam bidang pariwisata sebagian besar berhubungan dengan kapasitas daerah tujuan wisata, pengelolaan, penggunaan ruang untuk pariwisata, penilaian dampak pengunjung, pemetaan lingkungan pariwisata, pembuatan sistem manajemen informasi wisata serta hubungannya dengan pengambilan keputusan (Cvetković dan Jovanović, 2016).

Supak dkk. (2014) mengemukakan bahwa alasan beberapa bisnis / industri wisata sekarang ini tidak menggunakan aplikasi SIG dikarenakan kompleksitas dan biayanya. Hal ini sangat disayangkan, karena penggunaan SIG ini sangat bermanfaat untuk digunakan. Selain mengvisualisasikan daerah tujuan wisata bagi pengunjung, SIG ini juga dapat menemukan daerah-daerah yang berpotensi untuk dijadikan tujuan wisata baru, bahkan dapat membantu daerah tersebut, mulai dari perencanaan, pembentukan hingga strategi pemasaran yang sesuai (Supak dkk, 2014). SIG telah banyak digunakan untuk analisis dan menampilkan informasi spasial serta sumber daya alam, contohnya jalan, jaringan pipa, sumberdaya vegetasi dan mineral (Van der Merwe dan Van Niekerk, 2013). Perpaduan antara teknologi informasi dan pariwisata ini dapat menjadi motivator dalam ekonomi global karena memberikan peluang strategis bagi pertumbuhan ekonomi (Jovanović dan Njeguš, 2008).

Penggunaan SIG penting untuk diterapkan dalam dunia pariwisata Indonesia, sehingga produk wisata Indonesia dapat lebih dikenal lagi. Dengan statusnya sebagai negara kepulauan, Indonesia memiliki panorama keindahan alam yang tersebar di 13.466 pulau, salah satunya pulau Selayar (Giyanto dkk, 2017). WTO (2004) mengklasifikasikan Kabupaten Kepulauan Selayar kedalam wilayah yang memiliki tipologi destinasi gugusan kepulauan (Small Island), yang didalamnya terdapat kawasan perairan bahari, kawasan pantai, kawasan taman nasional dan cagar alam, serta situs sejarah (Nadjmi dkk, 2015).

Saat ini Kabupaten Kepulauan Selayar sedang melakukan pembenahan untuk menjadi salah satu KEK (Kawasan Ekonomi Khusus) Pariwisata Nasional. Berbagai perencanaan sudah mulai dipersiapkan untuk mewujudkan Kabupaten Kepulauan Selayar sebagai salah satu KEK Pariwisata Nasional. Penentukan arah pengembangan, hingga pada penyiapan sumberdaya manusia yang memiliki kompetensi yang tinggi di bidang pariwisata sudah mulai dilakukan. Dengan 
perkembangan wisata pulau Selayar yang sekarang ini, sistem informasi pariwisata sangat dibutuhkan oleh wisatawan untuk menentukan destinasi wisata yang dikehendaki. Dalam menentukan perencanaan perjalanan wisata, wisatawan membutuhkan gambaran daerah wisata seperti visualisasi tempat wisata, jalan yang harus dilalui, serta wisma atau tempat peristirahatan yang dapat ditempati selama perjalanan wisata.

Berdasarkan hasil penelitian Andi (2017), penyebab belum optimalnya pengembangan pariwisata Kabupaten Kepulauan Selayar ada tiga yaitu :

1. Birokrasi, dalam menjalankan tugasnya birokrasi Kabupaten Kepulauan Selayar masih belum profesional, hal ini terlihat dari kurangnya fasilitas yang terdapat pada lokasi objek wisata yang telah dikelola.

2. Sumberdaya, sumberdaya manusia yang ahli dalam bidang pariwisata juga masih kurang dan belum profesional.

3.Komunikasi, penyampaian informasi ke masyarakat masih belum bisa dimaksimalkan.

Berlandaskan hal-hal tersebut, maka dianggap penting dilakukan penelitian mengenai "Pemetaan Objek Wisata Bahari Kabupaten Kepulauan Selayar Berbasis Sistem Informasi Geografi” guna membantu meningkatkan informasi pariwisata yang ada di Kabupaten Kepulauan Selayar.

Penelitian ini dibatasi pada pemetaan obyek wisata bahari saja dengan melihat keunggulan destinasinya yang dapat dikunjungi sepanjang tahun. BPS Kabupaten Kepulauan Selayar mencatat, bahwa di tahun 2016 ada sekitar 850 wisatawan yang berkunjung ke Pantai Baloya (pantai bagian barat Pulau Selayar), 650 wisatawan mengunjungi pantai bagian timur Pulau Selayar, dan 234 wisatawan asing mengunjungi Taman Nasional Takabonerate.

\section{METODE PENELITIAN}

Jenis penelitian ini adalah penelitian kualitatif dengan metode deskriptif. Adapun variabel dalam penelitian ini yaitu lokasi objek wisata, jumlah objek wisata, atraksi wisata, jarak objek wisata, aksesibilitas, sarana dan prasarana wisata, terpeliharanya ODTW. Variabel dapat didefenisikan sebagai segala sesutu yang ditetapkan oleh peniliti untuk dipelajari sebagai jalan mendapatkan informasi tentang hal yang ingin dikaji dan diakhiri dengan penarikan kesimpulan (Sugiyono, 2006).

Teknik pengumpulan data yang digunakan dalam penelitian ini

1. Teknik observasi, dalam penelitian kualitatif, observasi yang dilakukan harus dalam konteks alamiah (naturalistik) (Gunawan, 2013).

2. Teknik pengukuran lapangan, alat bantu yang digunakan untuk mendapatkan data lokasi absolut setipa objek wisata yaitu GPS (Global Positioning System).

3. Teknik wawancara, wawancara yang dilakukan bersifat spontan berupa dialog antara peneliti dengan informan.

4. Teknik dokumentasi, Teknik dokumentasi digunakan untuk mendapatkan data-data noninsani berupa data dari dokumen dan rekaman (Gunawan, 2013)

Tabel 1. Instrumen Penelitian

\begin{tabular}{cll}
\hline No & Nama Alat / Bahan & Kegunaan \\
\hline $\mathbf{1}$ & Peta Admin Kab. & Sebagai peta \\
& Kep Selayar (JPG) & dasar / data \\
& Citra Kab. Kep & acuan \\
& Selayar (Ecw) & \\
$\mathbf{2}$ & Global Positioning & Ploting \\
& System (GPS) & lokasi
\end{tabular}


3 Alat Tulis Menulis

Mencatat

hasil

pengamatan

4 Kamera Digital

Meliput

objek

5 a. Hardware : Mengolah Laptop, Mouse dan

b. Softwre :

Sasplanet,

ArcGis 10.5

Teknik Analisi data yang digunakan yaitu teknik analisis data menggunakan aplikasi ArcGis 10.5 dan teknik analisis data deskriptif dengan membandingkan pengelolaan objek wisata yang dilakukan oleh pengerintah dengan standar SNI 8013 : 2014 tentang pengelolaan objek wisata alam dari segi kelestarian objek daya tarik wisata.

\section{HASIL DAN PEMBAHASAN}

Berdasarkan data yang diperoleh dari penelitian ini, deskripsi data penelitian mengungkapkan bahwa pengelolaan objek wisata bahari yang dilakukan merupakan pengelolaan yang mengedepankan aspek konservasi dan peran serta masyarakat dalam mengembangkan objek wisata bahari atau biasa disebut dengan ekowisata. Dalam memberdayakan masyarakatnya, pemerintah membentuk masyarakat sadar wisata untuk meningkatkan minat dan kesadaran masyarakat terhadap wisata. Hal ini sesuai dengan yang dikemukakan oleh Soekadijo (2000) dalam Yanuar V (2017) bahwa ekowisata dapat memberikan pengetahuan dan pengalaman yang dapat mempengaruhi terjadinya perubahan perilaku dan kesadaran masyarakat tentang pentingnya sumberdaya hayati dan ekosistemnya. Secara keseluruhan, pengelolaan yang telah dilakukan masih belum sesuai dengan SNI 8013 : 2014 .
Tidak adanya pencegahan terhadap tindakan vandalisme / pengrusakan menyebabkan objek wisata tidak terpelihara dengan baik. Hal ini ditandai dengan bebasnya pengunjung dan bahkan hewan ternak untuk keluar masuk di lokasi objek wisata. Selain itu, tidak adanya monitoring dan evaluasi yang kontinyu terhadap pengelolaan objek wisata menyebabkan kerusakan yang terjadi tidak mendapatkan perhatian secara khusus.
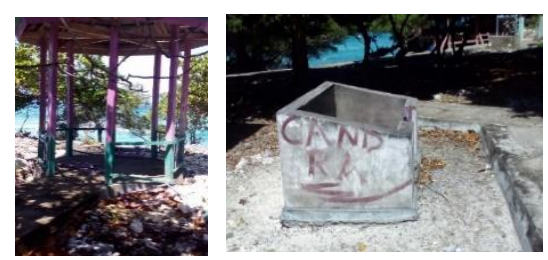

Gambar 1. Bentuk vandalisme yang terjadi Berdasarkan hasil penelitian, terdapat 38 objek wisata bahari Kabupaten Kepulauan Selayar. 7 objek wisata bahari dikelolah oleh pihak swasta yaitu pantai kahu, liang tarrusu, sumingi, pantai pinang, pantai bonetappalang, vila norsya dan pantai sunari. 11 objek wisata bahari dikelolah oleh desa yaitu lihu-lihukang, opu karajeng, tanjung merayu, punaga'n, ngapalohe, baloiya, sangkulu-kulu, batu karapu, makam karang, bahuluang dan pantai manyipi. 2 objek wisata bahari dikelolah oleh pemerintah dan desa yaitu pantai pa'ba'dilang dan tamamelong. 16 objek wisata bahari belum dikelolah yaitu pantai je;neiya, balojaha, bonemalea, liang kareta, ampangan, baba', patirangan, labuan nipaya, taloiya, rampa'rampangang, tana bo'dong, tana era, batu lohe, appa'tana, turungan, dan pantai laburu. 1 objek wisata bahari dikelolah oleh komunitas masyarakat. 1 objek wisata dikelolah langsung oleh Taman Nasional yaitu Taka Bonerate

Secara garis besar, proses pemetaan dengan menggunakan aplikasi 
ArcGis $\quad 10.5$ yaitu Registrasi, Georeferensing, Digitasi, Atribut Table dan Layout.

1. Registrasi, Langkah-langkah yang harus dilakukan yaitu klik icon (table of content)" untuk memunculkan kotak dialog layer, lalu klik kanan pada layer pilih properti, maka akan muncul kotak dialog baru. Pada kotak dialog yang muncul klik coordinate system - klik geographic coordinate system - pilih wolrd - pilih WGS 1984 - klik Ok

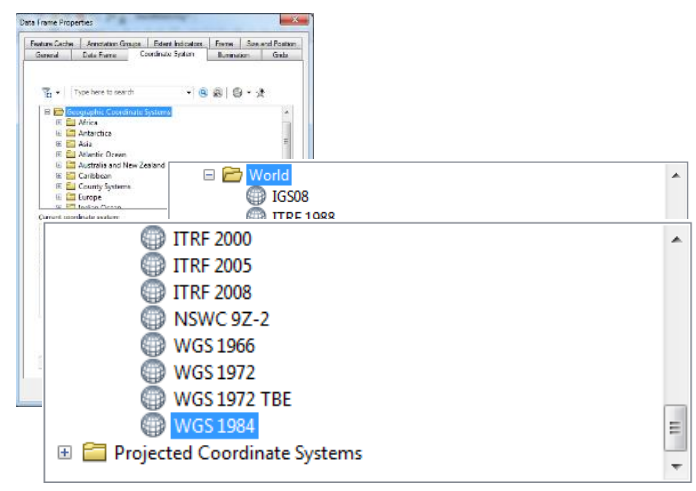

Gambar 2. Registrasi

2. Georeferensing, Langkah langkah yang harus dilakukan yaitu aktifkan tools Add control point yang terdapat pada toolbar georeferensing. Untuk memudahkan dalam memperjelas pertemuan garis lintang dan garis bujur dapat digunakan tools viewer atau tools zoom ,untuk memudahkan menggerakkan peta dapat digunakan tools pan. Setelah tools add control point aktif, untuk membuat titik kontrol point, klik kiri lalu klik kanan pada titik pertama titik pertemuan garis lintang dan garis bujur peta, setelah itu akan muncul kotak dialog baru. Karena sistem grid yang digunakan adalah sistem grid geografi, maka pada kotak dialog tersebut dipilih input DMS of Lon and Lat lalu masukkan koordinat pada kota dialog yang muncul, kemudian klik Ok.

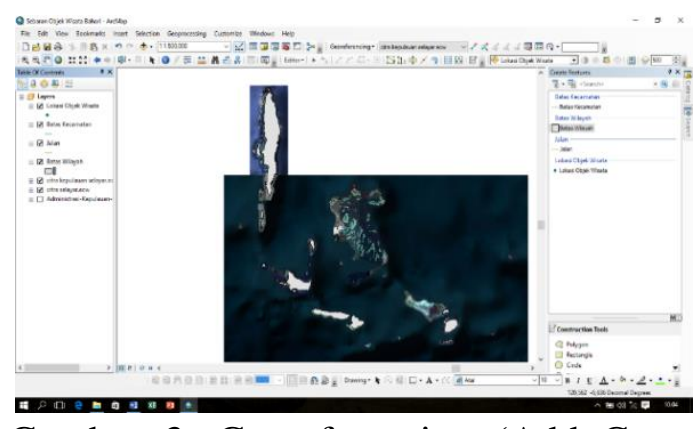

Gambar 3. Georeferensing (Add Control Point)

Lakukan Add control point minimal pada 4 titik pertemuan koordinat. Untuk mengakhiri proses georeferensing, maka dilakukan update georeferensing pada peta, langkah-langkah yang dilakukan sebagai berikut "klik georeferensing yang terdapat pada toolbar georefensing, lalu pilih update georefensing".

3. Digitasi, Langkah-langkah yang harus dilakukan yaitu aktifkan tools table of content - klik kanan pada tempat yang diinginkan - pilih shapefile. Lakukan pengaturan nama shapefile yang akan dibuat pada menu create shapefile. Setelah melakukan pengaturan pada kotak dialog shapefile selanjutnya aktifkan toolbar editor, pilih editor - klik start editing klik tools create features selanjutnya klik salah satu shapefile yang telah kita buat sebelumnya, maka proses digitsai dapat dimulai.

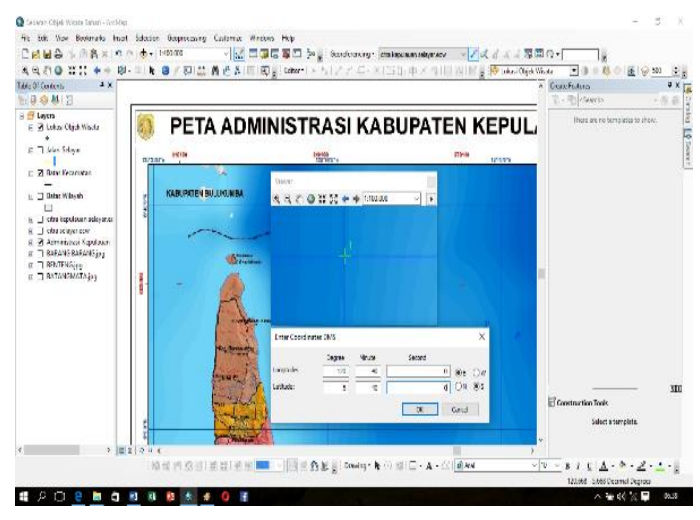

Gambar 4. Digitasi (Polygon) 
4.Atribut Table, Langkah - langkah yang harus dilakukan Klik kanan pada layer misalnya "Lokasi Objek Wisata Bahari" klik Open Atribut Table. Pada kotak dialog yang muncul, lakukan penambahan tabel sesuai informasi wisata yang ingin ditambahkan dengan cara klik tabel option - pilih Add Field. Pada menu add field, masukkan nama tabel yang diinginkan sedangkan untuk type, pilih Text lalu klik Ok. Maka akan muncul tabel baru untuk nama-nama setiap objek wisata.Untuk memulai pengisian informasi nama objek wisata, klik editor - pilih start editing pilih lokasi objek wisata. Setelah itu, dapat dilakukan pengisian nama objek wisata pada atribut tabel. Setelah nama objek wisata terisi save edit untuk mengakhiri proses editing. Lakukan proses atribut tabel diatas hingga semua informasi wisata yang diinginkan dapat terisi.

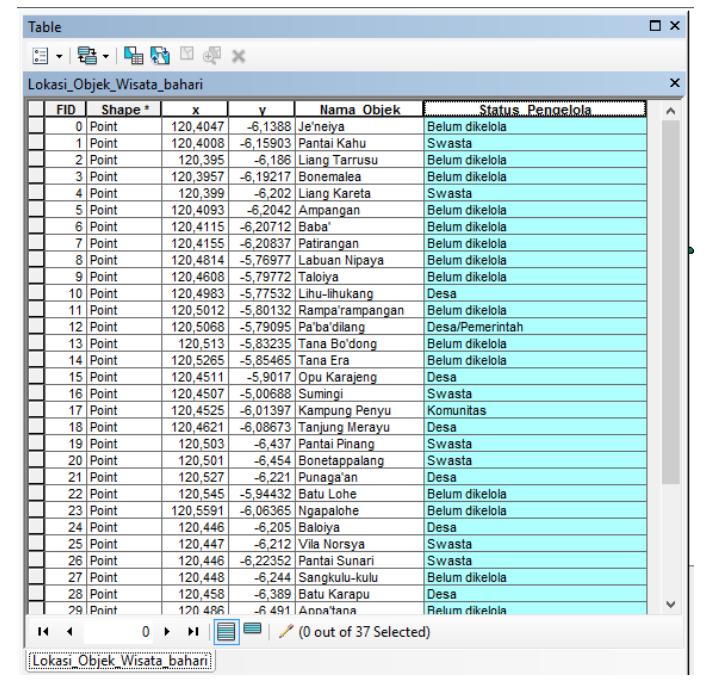

Gambar 5. Atribut Table

5.Layout, Pada tahapan layout dilakukan penambahan unsur-unsur peta yaitu judul peta, arah mata angin, skala, legenda, inset dan grid.

Untuk memulai layout, terlebih dahulu aktifkan layout view dengan cara klik view pada jendela ArcGis - lalu klik layout view.

Selanjutnya untuk melakukan penambahan unsur-unsur peta dapat dilakukan dengan cara mengklik menu insert pada jendela ArcGis. Setelah itu akan muncul beberapa pilihan diantaranya

$>$ Data Frame, berfungsi untuk menambahkan inset pada peta.

$>$ Title dan Text, berfungsi untuk menambahkan text pada peta, seperti Judul Peta dll.

$>$ Neatline, untuk menambahkan garis luar pada peta.

$>$ Legend, untuk menambahkan legenda pada peta

$>$ North Arrow, untuk menambahkan arah mata angin pada peta

> Scale Bar dan Scale text, untuk menambahkan skala pada peta.

Picture, untuk menambahakn gambar pada peta.

Untuk menmbahkan grid pada peta, klik kanan pada peta - kemudian klik properti $\neg-$ pilih Grid - klik next hingga finish lalu klik Ok Untuk menampilkan Gird. Pengaturan Grid dapat dilakukan dengan mengklik properti pada pilihan sebelumnya.

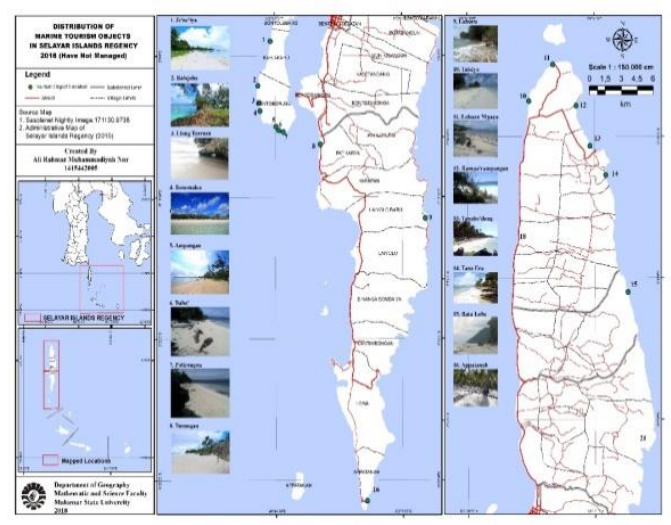

Gambar 6. Peta Sebaran Objek Wisata Bahari Kab. Kep.Selayar 


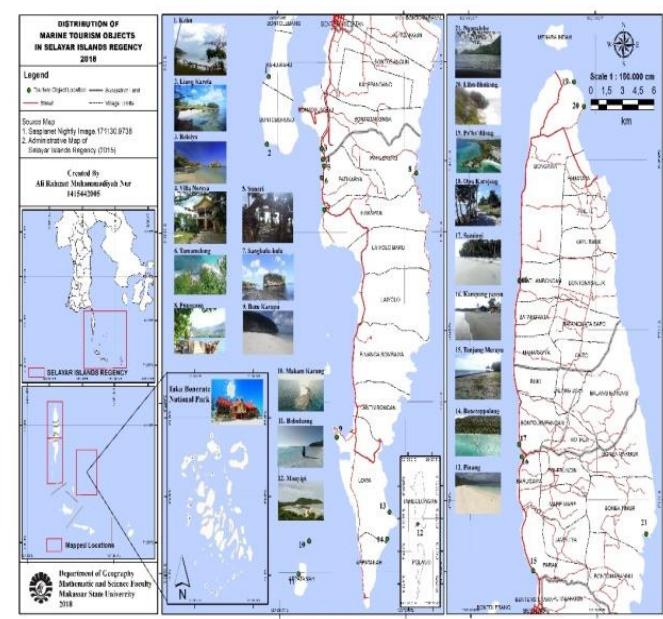

Gambar 7. Peta Sebaran Objek Wisata Bahari Kab. Kep.Selayar (Belum Terkelola)

\section{KESIMPULAN}

1. Pengelolaan objek wisata bahari Kabupaten Kepulauan Selayar merupakan pengelolaan yang mementingkan aspek konservasi dan peran serta masyarakat sebagai perencana, pelaksana, dan pengelola objek wisata. Pengelolaan objek wisata bahari Kabupaten Kepulauan Selayar dari segi kelestarian objek daya tarik wisata belum sesuai dengan SNI 8013:2014, terlihat dari pencegahan tindakan vandalisme/pengrusakan yang masih belum terlaksana dengan baik.

2. Kabupaten Kepulauan Selayar memiliki 38 objek wisata bahari, 22 telah terkelola oleh desa, pemerintah, komunitas dan swasta sedangkan 16 lainnya masih belum terkelola.

3. Proses pemetaan objek wisata bahari Kabupaten Kepulauan Selayar menggunakan ArcGis 10.5 secara garis besar melalui beberapa tahap diantaranya yaitu Registrasi, Georeferensing, Digitasi, Atribut Tabel dan Layout

\section{DAFTAR PUSTAKA}

Andi, J., 2017. Kebijakan Penataan Pariwisata Kabupaten Kepulauan Selayar (Phd Thesis).

BPS Kabupaten Kepulauan Selayar 2017. https://selayarkab.bps.go.id.

Cvetković, M., Jovanović, S.S., 2016. The Application Of Gis Technology In Tourism

Giyanto, Abrar, M., Hadi, T.A., Budiyanto, A., Hafizt, M., Salatalohy, A., Iswari, M.Y., 2017. Status Terumbu Karang Indonesia 2017. Puslit Oseanografi - Lipi., Jakarta.

Gunawan, I., 2013. Metode Penelitian Kualitatif Teori Dan Praktek, 1st Ed. Bumi Aksara, Jakarta.

Jovanović, V., Njeguš, A., 2008. The Application of Gis And Its Components In Tourism. Yugosl. J. Oper. Res. 18. Https://Doi.Org/10.2298/Yujor080 $2261 \mathrm{j}$

Nadjmi, N., Nuryanti, Soewarno, N., 2015. Pengembangan Destinasi Pariwisata Di Kepulauan Selayar Sulawesi Selatan.

Sugiyono, 2006. Metode Penelitian Pendidikan (Pendekatan Kuantitatif, Kualitatif, Dan R \& D). Alfabeta, Bandung.

Supak, S.K., Devine, H.A., Brothers, G.L., Rozier Rich, S., Shen, W., 2014. An Open Source Web-Mapping System For Tourism Planning And Marketing. J. Travel Tour. Mark. 31, 835-853. Https://Doi.Org/10.1080/10548408 $\underline{.2014 .890153}$

Van Der Merwe, J.H., Van Niekerk, A., 2013. Application Of Geospatial 
Technology For Gap Analysis In Tourism Planning For The Western

Cape 109.

Https://Doi.Org/10.1590/Sajs.2013/

1226

Yanuar,V. 2017. Ekowisata Berbasis Masyarakat Wisata Alam Pantai Kubu. Ziraa'ah. 42, 183-192. https://ojs.uniska-bjm.ac.id 